\title{
HUBUNGAN JUMLAH KUNJUNGAN IBU KE POSYANDU DENGAN STATUS GIZI BALITA DI WILAYAH KERJA PUSKESMAS AMPLAS
}

\author{
Donna Theresia \\ Universitas Sumatera Utara, Indonesia \\ Email: donnatheresiasimbolon@yahoo.co.id
}

\begin{abstract}
Weighing the child's weight every month to find out the nutritional status of children is one of the routine activities at the Posyandu. One effort to reduce the problem of malnutrition in children is to increase the participation of mothers in visiting and weighing their children to the Posyandu every month. This study aims to determine the relationship between the numbers of Posyandu visits with the nutritional status of children under five. This study uses a descriptive correlation design with a retrospective approach. The study was conducted in the working area of the Amplas Health Center with a sample of 382 mothers and children under five years old using a proportional random sampling technique based on the number of Posyandu. The measuring instrument used was an Observation sheet and a child's weight-weighing registration book. The analysis used in univariate analysis to determine the frequency distribution and bivariate analysis using chi-square. The results showed that 145 people (38\%) regularly visited Posyandu and 237 people (62\%) did not regularly visit Posyandu. Children who have good nutritional status are 203 people (53.1\%), malnutrition is 109 people (28.5\%), and malnutrition is 70 people (18.3\%). The bivariate analysis results obtained p-value $(0.00)$ $<a(0.05)$, so it can be concluded that there is a correlation between the number of Posyandu visits and the nutritional status of children under five. Suggestions for puskesmas staff to be able to conduct training and health education to cadres and improve health facilities in Posyandu.
\end{abstract}

Keywords: Toddler, mother, posyandu, nutritional status

\section{PENDAHULUAN}

Pemantauan pertumbuhan balita sangat penting dilakukan untuk mengetahui adanya hambatan pertumbuhan (growth faltering) secara dini.Penimbangan setiap bulan sangat perlu dilakukan untuk mengetahui hal tersebut. Pertumbuhan dan perkembangan pada balita dapat dipantau melalui penimbangan berat badan anak setiap bulan (Kementerian Kesehatan RI, 2015).

Penimbangan balita dapat dilakukan di berbagai tempat seperti posyandu, polindes, puskesmas atau sarana pelayanan kesehatan yang lain (Kementerian Kesehatan RI., 2015). Posyandu diasumsikan sebagai salah satu pendekatan yang tepat untuk menurunkan angka kematian dan kesakitan balita serta dapat meningkatkan status gizi balita (Busri, 2017). Kegiatan penimbangan merupakan salah satu kegiatan utama posyandu dan sebagai salah satu program perbaikan gizi masyarakat.Penimbangan balita dimaksudkan untuk memantau 
pertumbuhannya setiap bulan.

Nasional (RPJMN) 2015-2019 adalah

Penimbangan balita penting dilakukan menurunnya prevalensi masalah setiap satu bulan sampai lima tahun di posyandu untuk mengetahui tumbuh kembang balita (Depkes, 2016).

Cakupan penimbangan balita dapat diukur dengan frekuensi kunjungan balita untuk menimbang berat badan secara rutin enam bulan terakhir (Pusat Data dan Informasi Kemenkes RI, 2016). Penelitian Nurdin, Ediana, dan Dwi Martya Ningsih (2019) menyatakan terdapat hubungan antara balita yang ditimbang dengan status gizi buruk dan kurang, balita yang ditimbang tidak teratur memiliki resiko 1,5 kali mengalami gagal tumbuh dibandingkan yang ditimbang teratur.

Badan kesehatan dunia WHO (World Health Organization) pada tahun 2018 memperkirakan terdapat 51 juta balita mengalami masalah gizi. Kematian balita akibat masalah gizi sebesar 2,8 juta jiwa. Masalah gizi tertinggi terjadi di Negara Afrika dan Asia termasuk Indonesia (WHO, 2018). Hasil Survei Demografi dan Kesehatan Indonesia (SDKI, 2017) menunjukkan dari tahun ke tahun $\mathrm{AKB}$ mengalami penurunan signifikan, dari 68 kematian per 1.000 kelahiran hidup pada 1991, hingga 24 kematian per 1.000 kelahiran hidup pada tahun 2017.

Salah satu sasaran Rencana Pembangunan Jangka Menengah kekurangan gizi pada anak balita dari 19,6 persen pada tahun 2013 menjadi 17,0 persen pada target 2015-2019. Gizi kurang juga sangat erat hubungannya dengan anak stunting, berdasarkan data Riset Kesehatan Dasar (Riskesdas, 2018) angka kejadian stunting nasional mencapai 23,6 persen. Angka ini memiliki sebaran yang tidak sama antar propinsi. Angka anak yang mengalami stunting di beberapa provinsi mencapai 50 persen. Angka tersebut terus bertambah mulai tahun 2010 sebesar 35,6 persen.

Prevalensi gizi kurang dan gizi buruk di Sumatera Utara sebesar 22,4 persen masih termasuk dalam kategori tinggi. Berdasarkan dari data 33 kabupaten/kota di Sumatera Utara, 17 kabupaten/kota memiliki prevalensi gizi buruk dan kurang di atas angka prevalensi provinsi, yaitu berkisar antara 22,6 persen di Kabupaten Serdang Bedagai sampai 41,4 persen di Kabupaten Padang Lawas. Angka prevalensi gizi buruk dan kurang tertinggi terdapat pada 3 (tiga) kabupaten, yaitu Kabupaten Padang Lawas sebesar 41,4 persen, Nias Utara sebesar 40,7 persen dan Nias Barat sebesar 37,5 persen. Sedangkan berdasarkan sasaran MDG's 2015 prevalensi gizi buruk dan kurang pada balita sebesar 15,5 persen (Dinas 
Kesehatan Provinsi Sumatera Utara, 2017).

Hal ini membuat balita menjadi salah satu sasaran Posyandu yang cukup penting dibandingkan anak usia lainnya (Busri, 2017). Apabila anak mengalami gizi buruk, mengakibatkan pertumbuhan dan perkembangan anak terhambat, menurunkan daya tahan tubuh, dan memperlambat pembentukan sel otak sehingga berpengaruh pada kecerdasan anak (Hardiansyah \& Supariasah, 2017).

Partisipasi ibu harus ditingkatkan dalam upaya untuk mengurangi masalah gizi buruk pada anak dengan mengunjungi dan menimbang balitanya ke Posyandu setiap bulan (Pusat Data dan Informasi Kemenkes RI, 2016).

Kerutinan ibu dalam mengunjungi Posyandu akan sangat bermanfaat sebagai monitoring berat badan untuk mengetahui status gizi anak dengan menimbang berat badan setiap bulan agar dapat secara dini mendeteksi terhadap status kesehatan anak, sehingga dapat segera ditentukan intervensi lebih lanjut. Apabila ibu tidak secara rutin mengunjungi Posyandu mengakibatkan status gizi anak tidak terpantau dengan baik (Nurdin et al., 2019).

Studi pendahuluan yang dilakukan peneliti di Posyandu Mawar, di wilayah kerja Puskesmas Amplas Kelurahan Timbang Deli pada tanggal 07 Maret 2017, pada 10 orang tua yang membawa balitanya ke Posyandu, 4 orang tua rutin mengunjungi Posyandu dengan berat badan anaknya naik, dan 6 orang tua tidak rutin mengunjungi Posyandu, berat badan anaknya tetap bahkan mengalami penurunan. Ketidakrutinan kunjungan ibu yang kurang dari 8 kali dalam setahun, mengatakan karena ada kesibukan di rumah, menjemput anak ke sekolah, lupa jadwal Posyandu, anak yang menolak dibawa ke Posyandu sehingga tidak bisa datang. Berdasarkan uraian diatas, peneliti tertarik untuk melakukan penelitian tentang hubungan jumlah kunjungan ibu ke posyandu dengan status gizi balita.

\section{METODE}

Penelitian ini dilakukan di wilayah kerja Puskesmas Amplas Kota Medan yang dimulai dari bulan Maret sampai bulan April 2020. Penelitian ini merupakan jenis penelitian kuantitatif yang menggunakan desain penelitian deskriptif korelasi dengan pendekatan retrospektif. Rancangan ini menghubungkan variabel yang satu dengan variabel yang lainnya, selanjutnya mengujinya secara statistik (uji hipotesis) atau dikenal dengan uji korelasi yang menghasilkan koefisien korelasi (Swarjana \& I Ketut Swarjana, 2012).

Populasi penelitian ini adalah seluruh ibu dan balita di wilayah kerja 
Puskesmas Amplas yang berjumlah 13.255 balita. Perhitungan sampel didapatkan sebanyak 382 orang responden. Penentuan jumlah sampel dari tabel Isaac dan Michael memberikan kemudahan untuk menentukan jumlah sampel berdasarkan tingkat kesalahan sepuluh persen dan teknik pengambilan sampel dalam penelitian ini dilakukan secara proporsional random sampling. yaitu pengambilan sampel yang memperhatikan pertimbangan unsurunsur atau kategori dalam populasi penelitian. Cara ini digunakan karena populasinya cukup homogen, jumlah populasi sangat besar dan populasi menempati daerah yang luas. Alat pengumpulan data yang digunakan dalam penelitian ini adalah lembar observasi dan KMS.

Analisa data menggunakan analisa univariat untuk mendeskripsikan karakteristik responden terkait (umur ibu, umur anak, jenis kelamin anak, pendidikan terakhir ibu, pekerjaan ibu, dan pendapatan keluarga dalam sebulan), jumlah kunjungan ibu ke Posyandu, dan status gizi balita. Analisa bivariat untuk mengetahui hubungan jumlah kunjungan Posyandu dengan status gizi balita dengan menggunakan uji chi-square.

\section{HASIL DAN PEMBAHASAN}

\section{Hasil}

1. Analisis Univariat

Analisa univariat dapat dilihat pada tabel di bawah ini

Tabel 1. Distribusi Karakterisitik Responden

\section{Karakteristik Jumlah Persentase} (n) (\%)

\begin{tabular}{|c|c|c|}
\hline \multicolumn{3}{|c|}{ Umur Ibu (tahun) } \\
\hline $17-25$ & 43 & 11,3 \\
\hline $26-35$ & 327 & 85,6 \\
\hline $36-45$ & 12 & 3,1 \\
\hline $\begin{array}{l}\text { Umur } \\
\text { (bulan) }\end{array}$ & anak & \\
\hline $12-24$ & 114 & 29,8 \\
\hline $25-36$ & 184 & 48,2 \\
\hline $37-48$ & 52 & 13,6 \\
\hline $49-60$ & 32 & 8,4 \\
\hline
\end{tabular}

\section{Jenis kelamin} (anak)

$\begin{array}{lrr}\text { Laki-laki } & 202 & 53,4 \\ \text { Perempuan } & 180 & 46,6 \\ \text { Pendidikan } & & \\ \text { SD } & 1 & 0,3 \\ \text { SMP } & 46 & 12 \\ \text { SMA } & 325 & 85,1 \\ \text { Diploma } & 7 & 1,8 \\ \text { S1 } & 3 & 0,8 \\ \text { Pekerjaan } & & \\ \text { Ibu rumah } & 255 & 66,75 \\ \text { tangga } & & \\ \text { Wiraswasta } & 36 & 9,42 \\ \text { PNS } & 48 & 12,56 \\ \text { Karyawan } & 43 & 11,25 \\ \text { swasta } & & \end{array}$

\begin{tabular}{lrr}
$\begin{array}{l}\text { Status } \\
\text { (BB/Umur) }\end{array}$ & gizi & \\
$\quad$ Gizi baik & 203 & 53,1 \\
Gizi kurang & 109 & 28,5 \\
Gizi buruk & 70 & 18,3 \\
\hline Total & 382 & 100 \\
\hline
\end{tabular}

Karakteristik responden seperti umur ibu, umur anak, jenis kelamin anak, pendidikan, pekerjaan, dan status gizi anak, disajikan pada Tabel 1. Tabel ini menggambarkan bahwa mayoritas umur 
ibu berada pada rentang 26-35 tahun sebanyak 327 orang $(85,6 \%)$. Responden anak mayoritas berumur pada rentang 25-36 bulan sebanyak 184 orang $(48,2 \%)$ mayoritas berjenis kelamin laki-laki sebanyak 204 orang $(53,4 \%)$. Responden ibu mayoritas berpendidikan SMA sebanyak 325 orang $(85,1 \%)$ mayoritas responden dengan status pekerjaan sebagai ibu rumah tangga (IRT) sebanyak 255 orang $(66,75$ $\%)$.dengan anak berstatus gizi baik sebanyak $203(53,1 \%)$.

Tabel 2.Distribusi Frekuensi Kunjungan ke Posyandu

\begin{tabular}{lcc}
\hline \multicolumn{1}{c}{ Variabel } & Jumlah & $\begin{array}{c}\text { Persentase } \\
(\%)\end{array}$ \\
\hline $\begin{array}{l}\text { Kunjungan ke } \\
\text { posyandu }\end{array}$ & & \\
\hline $\begin{array}{l}\text { Rutin } \\
\text { kunjungan } \geq 4 \\
\text { kali dalam 6 } \\
\text { bulan }\end{array}$ & 145 & 38,0 \\
\hline $\begin{array}{l}\text { Tidak rutin } \\
\text { kunjungan }<4\end{array}$ & 237 & 62,0 \\
kali dalam 6 \\
bulan)
\end{tabular}

Distribusi frekuensi kunjungan ibu ke posyandu dapat dilihat pada Tabel 2, responden yang tidak rutin melakukan kunjungan ke posyandu sebanyak 237 orang $(62 \%)$ dan yang rutin melakukan kunjungan ke posyandu sebanyak 145 orang (38\%).

\section{Analisis Bivariat}

Tabel 3. Hubungan Kunjungan Ibu Ke Posyandu Dengan Status Gizi Balita

\begin{tabular}{|c|c|c|c|c|c|}
\hline \multirow{3}{*}{$\begin{array}{c}\text { Kunju- } \\
\text { ngan } \\
\text { Posyan } \\
\text { du }\end{array}$} & \multicolumn{3}{|c|}{ Status gizi } & \multirow{2}{*}{ Total } & \multirow{2}{*}{$\begin{array}{c}P \\
\text { value }\end{array}$} \\
\hline & Baik & Kurang & Buruk & & \\
\hline & $\begin{array}{c}n \\
(\%)\end{array}$ & $\begin{array}{c}n \\
(\%)\end{array}$ & $\begin{array}{c}\mathbf{n} \\
(\%)\end{array}$ & $\begin{array}{c}\mathbf{n} \\
(\%)\end{array}$ & \\
\hline Rutin & $\begin{array}{c}100 \\
(69,0)\end{array}$ & $\begin{array}{c}33 \\
(22,8)\end{array}$ & $\begin{array}{c}12 \\
(8,3)\end{array}$ & $\begin{array}{c}145 \\
(100)\end{array}$ & \\
\hline $\begin{array}{l}\text { Tidak } \\
\text { rutin }\end{array}$ & $\begin{array}{c}103 \\
(43,5)\end{array}$ & $\begin{array}{c}76 \\
(32,1)\end{array}$ & $\begin{array}{c}58 \\
(24,5)\end{array}$ & $\begin{array}{c}237 \\
(100)\end{array}$ & 0,00 \\
\hline Total & $\begin{array}{c}203 \\
(53,1) \\
\end{array}$ & $\begin{array}{c}109 \\
(28,5)\end{array}$ & $\begin{array}{c}70 \\
(18,3)\end{array}$ & $\begin{array}{c}382 \\
(100)\end{array}$ & \\
\hline
\end{tabular}

Hasil analisis bivariat dapat dilihat pada Tabel 3, responden yang rutin mengunjungi posyandu mempunyai gizi baik sebanyak 100 orang $(69,0 \%)$ dan responden yang tidak rutin mengunjungi Posyandu mempunyai gizi baik sebanyak 103 orang (43,5\%). Hasil uji statistik didapatkan $p$ value $(0,00)<\mathrm{a}$ $(0,05)$, sehingga dapat disimpulkan ada hubungan jumlah kunjungan Posyandu dengan status gizi balita.

\section{Pembahasan}

\section{Umur}

Hasil penelitian menunjukkan mayoritas umur responden yang berkunjung ke posyandu adalah 26-35 tahun yaitu sebanyak 327 orang $(85,6 \%)$ dan mayoritas umur anak adalah 25- 36 bulan yaitu sebanyak 184 orang $(48,2 \%)$.

Umur seorang ibu merupakan salah satu yang berkaitan dengan pola pengasuhan anak, dimana usia merupakan satu hal yang identik dengan 
pengalaman dan pengetahuan seseorang yang mana semakin tua orang akan diidentikkan mempunyai pengetahuan yang lebih dibandingkan dengan usia muda. Menurut (Mustika \& Syamsul, 2018) bahwa pada ibu yang berumur muda dan baru memiliki anak akan cenderung memberikan perhatian yang lebih besar terhadap anak.

Hal ini sama dengan hasil penelitian Busri (2017) tentang faktor yang berhubungan dengan perilaku kunjungan ke Posyandu pada ibu balita, didapatkan hasil bahwa mayoritas umur ibu yang berkunjung ke Posyandu yaitu rentang umur 26-35 tahun. Rentang umur pernikahan bagi perempuan yang disarankan oleh Badan Kependudukan dan Keluarga Berencana Nasional (BKKBN, BPS, \& Kemenkes RI, 2018) yakni pada rentang umur 20-25 tahun karena pada umur ini sudah matang secara biologis dan psikologis serta bisa berpikir dewasa dalam membangun rumah tangga. Ibu akan mempunyai anak pertama pada saat berumur 23-30 tahun karena pada umur tersebut resiko yang dialami ibu saat hamil dan melahirkan lebih sedikit.

Umur anak 25-36 bulan adalah masa toddler, pada umur ini ibu masih khawatir dengan kesehatan anaknya, sehingga ibu tetap membawa anaknya ke Posyandu untuk menimbang berat badan dan memantau pertumbuhan serta perkembangan anaknya (Fitri, 2017). Hal ini sama dengan hasil penelitian (Asdhany \& Kartini, 2012), tentang hubungan tingkat partisipasi ibu dalam kegiatan Posyandu dengan status gizi anak balita, didapatkan bahwa mayoritas umur anak yang berkunjung ke Posyandu yaitu umur 24-59 bulan (71\%).

\section{Jenis kelamin}

Hasil penelitian menunjukkan mayoritas responden anak berjenis kelamin laki-laki sebanyak 202 orang $(53,4 \%)$. Data dari Puskesmas Amplas tahun 2016, dari 8300 anak balita (1-5 tahun) lebih banyak berjenis kelamin laki-laki daripadaperempuan yakni lakilaki sebanyak 4344 orang dan perempuan sebanyak 3956 orang, sehingga anak yang lebih banyak datang ke posyandu berjenis kelamin laki-laki. Hal ini sama dengan hasil penelitian Handayani (2017), tentang hubungan tingkat pendapatan keluarga dengan status gizi balita, didapatkan hasil bahwa mayoritas responden yaitu berjenis kelamin laki-laki.

\section{Pendidikan}

Hasil penelitian menunjukkan mayoritas pendidikan responden ibu yaitu SMA sebanyak 325 orang $(85,1 \%)$. Hal ini sama dengan hasil penelitian (Yuliansyah, 2018) tentang hubungan antara tingkat partisipasi ibu di Posyandu dengan status gizi balita, 
juga didapatkan mayoritas pendidikan responden yaitu pendidikan SMA (70\%). Hasil penelitian Kurniasari dan Nurhayati (2017) tentang hubungan pendidikan orang tua dengan status gizi balita, didapatkan bahwa ada hubungan antara pendidikan orang tua dengan status gizibalita.

Ibu berpendidikan SMA meyakini pentingnya membawa anak berkunjung ke Posyandu dalam memantau pertumbuhan, perkembangan, status gizi, dan pentingnya pelayanan kesehatan (Kurniasari \& Nurhayati, 2017). Hasil penelitian ini didapatkan mayoritas responden ibu berpendidikan SMA dengan ibu bekerja sebagai Ibu Rumah Tangga (IRT), sehingga mereka punya waktu luang untuk membawa anaknya ke Posyandu.

\section{Pekerjaan}

Hasil penelitian menunjukkan mayoritas pekerjaan responden yaitu Ibu Rumah Tangga (IRT) sebanyak 347 orang $(90,8 \%)$. Hal ini sama dengan hasil penelitian (Kurniasari \& Nurhayati, 2017), tentang hubungan tingkat pastisipasi ibu dalam kegiatan Posyandu dengan status gizi anak balita, didapatkan bahwa mayoritas pekerjaan responden yaitu tidak bekerja $(83,9 \%)$.

Kegiatan Posyandu yang dilakukan pada pagi hari sehingga kebanyakan ibu yang mengunjungi Posyandu berstatus tidak bekerja. Ibu yang bekerja, terikat oleh jam kerja sehingga ibu tidak dapat membawa balitanya ke Posyandu pada hari jam kerja. Ibu yang tidak bekerja mempunyai waktu luang lebih besar dalam memberikan perhatian kepada anaknya dengan membawa anaknya ke Posyandu (Putri, Sulastri, \& Lestari, 2015).

\section{Kunjungan ke Posyandu}

Hasil penelitian menunjukkan bahwa responden yang tidak membawa anaknya berkunjung ke posyandu sebanyak 237 orang (62\%) dan yang rutin mengunjungi Posyandu sebanyak 145 orang (38\%). Penelitian ini lebih banyak responden ibu tidak membawa anaknya ke posyandu dikarenakan beberapa masalah yakni kurangnya fasilitas kesehatan yang ada di posyandu, kurangnya kualitas pelayanan kesehatan, dan kurangnya kegiatan dari Puskesmas sehingga ibu tidak tertarik untuk datang membawa anaknya ke posyandu. Hal ini diperkuat dengan penelitian (Handayani, 2017) tentang hubungan kualitas pelayanan kesehatan posyandu dengan frekuensi kunjungan ibu balita ke posyandu, ada hubungan antara kualitas pelayanan kesehatan posyandu dengan frekuensi kunjungan ibu balita.

\section{Status gizi balita}

Hasil penelitian menunjukkan status gizi responden yaitu gizi baik sebanyak 203 orang $(53,1 \%)$. Hasil penelitian ini 
didapatkan responden ibu yang tidak rutin mengunjungi posyandu memiliki gizi baik sebanyak 103 orang $(43,5 \%)$ hampir sama dengan yang rutin sebanyak 100 orang $(69,0 \%)$. Ibu yang tidak rutin ke posyandu menyebabkan berat badan anak tidak terpantau dengan baik, sehingga masih ditemukan anak berstatus gizi kurang dan status gizi buruk. Hal ini dapat dicegah apabila ibu rutin ke pelayanan kesehatan karena Ibu akan diberikan penyuluhan terkait kesehatan ibu dan anak oleh tenaga kesehatan dari Puskesmas, sehingga dapat meningkatkan pemahaman ibu tentang status gizi, pertumbuhan dan perkembangan anaknya (Kemenkes RI, 2015).

\section{Hubungan jumlah kunjungan Ibu ke Posyandu dengan status gizi balita}

Hubungan jumlah kunjungan Ibu ke Posyandu dengan status gizi balita didapatkan ada hubungan jumlah kunjungan ibu ke posyandu dengan status gizi balita. Semakin rutin ibu melakukan kunjungan ke posyandu maka status gizi balita akan baik juga. Hal ini dapat dilihat dari balita yang rutin ibu melakukan kunjungan ke posyandu memiliki persentase status gizi baik $69,0 \%$ dibanding yang ibu yang tidak rutin melakukan kunjungan ke posyandu, balitanya memiliki status gizi baik memiliki persentase $43 \%$.
Hal ini diperkuat dengan hasil penelitian (Oktavianis, 2016) tentang hubungan keaktifan keluarga dalam kegiatan Posyandu dengan status gizi balita, didapatkan bahwa ada hubungan antara keaktifan keluarga ke Posyandu dengan status gizi balita. Penelitian Muharry, Kumalasari, dan Dewi (2017) tentang hubungan antara keaktifan kunjungan ibu dengan perkembangan status gizi anak usia 6-23 bulan, didapatkan bahwa keaktifan kunjungan ibu ke posyandu juga mempengaruhi status gizi anak.

Beberapa faktor yang paling mempengaruhi keaktifan kunjungan ibu datang ke posyandu di wilayah kerja Puskesmas Amplas yaitu umur ibu, diperoleh data berdasarkan karakteristik responden sebagian besar pada rentang usia adalah 26-35 tahun yaitu sebanyak 327 orang $(85,6 \%)$ yang tergolong dalam usia produktif, karena ibu dengan usia dewasa muda lebih mudah menerima instruksi dan cenderung lebih berhati-hati dalam melakukan yang terbaik baik bagi anaknya. Sesuai dengan Putri, Sulastri, dan Lestari (2015) salah satu faktor yang mempengaruhi partisipasi ibu untuk menimbang balita ke posyandu adalah usia dewasa muda ( $<36$ tahun). Hal ini disebabkan karena ibu dalam usia produkif lebih banyak memanfaatkan pelayanan kesehatan seperti 
penimbangan berat badan, pemberian makanan tambahan, imunisasi dan penanggulangan diare sehingga status gizi balita menjaditerkontrol.

Sesuai dengan (Khotimah \& Kuswandi, 2015) mengemukakan bahwa ibu berusia muda dapat mencegah terjadinya gizi buruk pada balitanya. Berdasarkan karakteristik reponden selain umur yaitu pendidikan ibu yang sebagian besar berpendidikan terakhir yaitu SMA. Hal ini sesuai dengan Wati (2014) menyatakan bahwa pendidikan ibu yang relatif tinggi akan meningkatkan pengetahuan gizi serta praktek gizi yang secara tidak langsung memperbaiki perilaku ibu sehingga keaktifan kunjungan ibu juga dapat meningkat. Sesuai dengan Heniarti (2015) mengemukakan bahwa peran pendidikan sangatlah penting untuk mempermudah menerima informasi. Semakin tinggi pendidikan maka semakin mudah menerima informasi dan memperoleh pengetahuan, sehingga dapat merubah perilaku seseorang seperti perilaku ibu yang aktif membawa balitanya ke posyandu.

\section{KESIMPULAN DAN SARAN}

\section{Kesimpulan}

Setelah dilakukan penelitian tentang hubungan jumlah kunjungan posyandu dengan status gizi balita di wilayah kerja Puskesmas Amplas dapat disimpulkan bahwa ada hubungan jumlah kunjungan ibu ke posyandu dengan status gizi balita.

\section{Saran}

Hasil penelitian ini diharapkan menjadi informasi bagi tenaga kesehatan yang ada di Puskesmas agar dapat melakukan pelatihan serta penyuluhan kepada kader posyandu, sehingga dapat meningkatkan pengetahuan para kader tentang kesehatan, pengelolaan Posyandu dengan baik, dan pemantauan status gizi anak.

\section{DAFTAR PUSTAKA}

Asdhany, C., \& Kartini, A. (2012). Hubungan tingkat partisipasi ibu dalam kegiatan posyandu dengan status gizi anak balita (studi di Kelurahan Cangkiran Kecamatan Mijen Kota Semarang). Journal of Nutrition College. https://doi.org/10.14710/jnc.v1i1.424

BKKBN, BPS, \& Kemenkes RI. (2018). Survei Demografi Kesehatan Indonesia. In USAID.

Busri. (2017). Faktor-faktor yang menyebabkan rendahnya peran ibu balita ke Posyandu Desa Sumber Datar Wilayah Kerja Puskesmas Keranji tahun 2016. Jurnal Doppler Universitas Pahlawan Tuanku Tambusai.

Depkes. (2016). Profil Kesehatan RI 2015. In Profil Kesehatan Indonesia Tahun 2015. https://doi.org/10.1111/evo.12990

Dinas Kesehatan Provinsi Sumatera Utara. (2017). Profil Kesehatan Provinsi Sumatera Utara tahun 2017 Indonesia. Profil Kesehatan Provinsi Sumatera Utara Tahun 2017 Indonesia. https://doi.org/10.1017/CBO9781107 415324.004.

Fitri, A. W. G. (2017). Peran kelompok 
bermain dalam proses sosialisasi anak usia dini di kecamatan Sukorejo Kabupaten Kendal Semarang. DIGILIB UNNES.

Handayani, I. K. (2013). Faktor - faktor yang mempengaruhi partisipasi ibu membawa balita ke posyandu Tambun Baru Desa Pahlawan Setia Kecamatan Tarumajaya Bekasi Jawa Barat.

Handayani, R. (2017). Faktor-faktor yang berhubungan dengan status gizi pada anak balita. Jurnal Endurance. https://doi.org/10.22216/jen.v2i2.174 2

Hardiansyah, \& Supariasah, I. D. (2017). Ilmu Gizi Teori dan Aplikasi. In Gizi Bayi dan Balita.

Heniarti, S. (2015). Hubungan tingkat pendidikan, tingkat pengetahuan dan sikap ibu balita dengan kunjungan ke posyandu di wilayah kerja Puskesmas Belawang. Jurnal Publikasi Kesehatan Masyarakat Indonesia.

Kemenkes. (2015). Infodatin-Asi. Profil Kesehatan Indonesia. https://doi.org/10.1300/J095v11n02_ 07

Kementerian Kesehatan RI. (2015). Kementerian Kesehatan Republik Indonesia. In Kementerian Kesehatan RI. Sekretariat $r$ Jenderal. Rencana Strategis Kementerian Kesehatan Tahun Rencana Strategis Kementerian Kesehatan Tahun. https://doi.org/351.077 Ind r

Kementerian Kesehatan RI. (2015). Rencana Strategis Kementerian Kesehatan Republik Indonesia Tahun 2015-2019. Pusat Komunikasi Publik. https://doi.org/351.077 Ind r

Khotimah, H., \& Kuswandi, K. (2015). Hubungan karakteristik ibu dengan status gizi balita di desa Sumur Bandung Kecamatan Cikulur Kabupaten Lebak tahun 2013. Jurnal Obstretika Scienta.

Kurniasari, A. D., \& Nurhayati, F. (2017). Hubungan antara tingkat pendidikan, pekerjaan dan pendapatan orang tua dengan status gizi pada siswa SD Hangtuah 6
Surabaya. Jurnal Pendidikan Olahraga Dan Kesehatan.

Muharry, A., Kumalasari, I., \& Dewi, E. R. (2017). Faktor yang mempengaruhi status gizi balita di puskesmas Nelayan Kota cirebon. JIKES (Jurnal Ilmu Kesehatan). https://doi.org/10.33006/ji-

kes.v1i1.41

Mustika, W., \& Syamsul, D. (2018). Analisis permasalahan status gizi kurang pada balita di Puskesmas Teupah Selatan Kabupaten Simeuleu. Jurnal Kesehatan Global. https://doi.org/10.33085/jkg.v1i3.395 2

Nurdin, N., Ediana, D., \& Dwi Martya Ningsih, N. S. (2019). Faktor-faktor yang berhubungan dengan partisipasi ibu balita ke posyandu di Jorong Tarantang. Jurnal Endurance. https://doi.org/10.22216/jen.v4i2.362 6

Oktavianis. (2016). Faktor-faktor yang berhubungan dengan status gizi pada balita di Puskesmas Lubuk Kilangan. Jurnal Human Care.

Pusat Data dan Informasi Kemenkes RI. (2016). Infodatin: Situasi Balita Pendek. ACM SIGAPL APL Quote Quad.

Putri, R. F., Sulastri, D., \& Lestari, Y. (2015). Faktor-faktor yang berhubungan dengan status gizi anak balita di wilayah kerja Puskesmas Nanggalo Padang. Jurnal Kesehatan Andalas. https://doi.org/10.25077/jka.v4i1.231

Riskesdas. (2018). Riset Kesehatan Dasar 2018. Kementrian Kesehatan Republik Indonesia. https://doi.org/1 Desember 2013

SDKI. (2017). Laporan Pendahuluan Survey Demografi dan Kesehatan Indonesia 2017. In Survey Demografi dan Kesehatan Indonesia 2017. https://doi.org/10.1111/j.14710528.2007.01580.x

Swarjana, I. K., \& I Ketut Swarjana, S. (2012). Metodologi Penelitian Kesehatan. Yogyakarta: ANDI.

Wati, I. K. (2014). Faktor-faktor yang berhubungan dengan minat ibu 
terhadap kunjungan ke posyandu di

Kelurahan Kembangarum Kota

Semarang. Jurnal Stikes Ngudi

Waluyo.

WHO. (2018). World Health Statistic

2018: Monitoring Health For The SDGs. World Development. https://doi.org/10.1016/j.worlddev.20 18.08.012

Yuliansyah, et al. (2018). Analisis faktor yang berhubungan dengan partisipasi ibu membawa anaknya ke posyandu Kelurahan Kricak Wilayah

Kerja Puskesmas Tegalrejo

Yogyakarta. Jurnal Keperawatan

Respati Yogyakarta. 